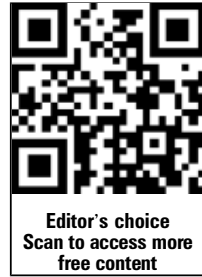

10.1136/eb-2012-100608

${ }^{1}$ PenTAG, University of Exeter, Peninsula Medical School, Exeter, Devon, UK

${ }^{2}$ Karen Welch Information Consultancy, Fareham, UK

${ }^{3}$ European Centre for

Environment and Human Health, University of Exeter, Truro, UK

Correspondence to: Dr Mary Bond

PenTAG, Peninsula Medical School, University of Exeter, Veysey Building, Salmon Pool Lane, Exeter EX2 4SG, Devon, UK; mary.bond@pms.ac.uk

\title{
Psychological consequences of false-positive screening mammograms in the UK
}

\section{Mary Bond, ${ }^{1}$ Toby Pavey, ${ }^{1}$ Karen Welch, ${ }^{2}$ Chris Cooper, ${ }^{1}$ Ruth Garside, ${ }^{3}$ Sarah Dean, ${ }^{1}$ Christopher J Hyde ${ }^{1}$}

\section{Abstract}

Objectives To identify the psychological effects of falsepositive screening mammograms in the UK.

Methods Systematic review of all controlled studies and qualitative studies of women with a false-positive screening mammogram. The control group participants had normal mammograms. All psychological outcomes including returning for routine screening were permitted. All studies had a narrative synthesis.

Results The searches returned seven includable studies (7/4423). Heterogeneity was such that meta-analysis was not possible. Studies using disease-specific measures found that, compared to normal results, there could be enduring psychological distress that lasted up to 3 years; the level of distress was related to the degree of invasiveness of the assessment. At 3 years the relative risks were, further mammography, 1.28 (95\% CI 0.82 to 2.00), fine needle aspiration 1.80 (95\% CI 1.17 to 2.77 ), biopsy 2.07 (95\% CI 1.22 to 3.52) and early recall 1.82 (95\% CI 1.22 to 2.72). Studies that used generic measures of anxiety and depression found no such impact up to 3 months after screening. Evidence suggests that women with false-positive mammograms have an increased likelihood of failing to reattend for routine screening, relative risk 0.97 (95\% CI 0.96 to 0.98) compared with women with normal mammograms.

Conclusions Having a false-positive screening mammogram can cause breast cancer-specific distress for up to 3 years. The degree of distress is related to the invasiveness of the assessment. Women with false-positive mammograms are less likely to return for routine assessment than those with normal ones.

\section{Introduction}

The benefits and harms arising from mammography screening are a matter of national debate in the UK. ${ }^{1}{ }^{2}$ The number of lives saved, amount of over diagnosis and degree of distress caused by 'false alarms' are hotly contested. $^{3-7}$ This debate has led to a review of UK breast cancer screening services currently being undertaken by Professor Sir Michael Richards.

The negative psychological impact of false-positive screening results has been documented in the fields of prenatal and cervical cancer screening. ${ }^{8} 9$ Their impact on the medium to long-term psychological well-being and behaviour of women who receive false-positive results from routine mammography has been less well researched and synthesised.

Systematic reviews and meta-analyses in Europe and America have found conflicting evidence about the psychological impact from receiving a false-positive mammogram and also on future attendance at routine screening. ${ }^{70-14}$ Most studies showed a negative impact from receiving a false-positive mammogram on measures of, well-being, depression and anxiety compared to women with normal screening results. The exception to this was the meta-analysis of generic psychological measures by Salz et $a l^{10}$ which showed that only anxiety was positively correlated with having a falsepositive mammogram (0.03 (95\% CI 0.00 to 0.07)). The evidence varied concerning whether psychological distress had a short-term ( $<1$ month after assessment) or long-term impact. There was some evidence that the degree of impact varied with the severity of the reassessment test; with women undergoing biopsy showing greater psychological distress than those with a repeat mammogram. ${ }^{13}$

The results for the impact of receiving a false-positive mammogram on returning for the next routine screening mammogram give a more complex picture. Armstrong et $a l^{15}$ found there was no statistically significant difference between groups in the likelihood of returning for routine breast screening, although it is not clear whether the studies were reporting actual attendance or intention to attend. This may be important as Bankhead et al ${ }^{14}$ found that women were more likely to say that they had an intention to attend their next routine mammogram than actually do so. Other studies showed a variation in the effect of a false-positive mammogram on returning for screening according to location; with European women unaffected in this domain, Canadian women less likely to return and women from the USA more likely to return for routine mammography. ${ }^{7}$

These systematic reviews had a wider geographical scope than the UK and included studies of the shortterm impact of a false-positive mammogram (less than 1 month from assessment). Many of the included studies were based on programmes with a different approach and periodicity to that of the UK where mammography screening is national, free, opt-out and uses double screening of mammograms. Additionally the UK service runs on a 3 years cycle of invitations to women aged 47-73. In particular, the US system differs as it comes from a mixture of public and private providers and is insurance-based, opt-in, uses single screening, which produces a higher number of false-positives and has until recently recommended screening annually from the age of 40. Most European countries offer screening for the 50-69 age group but generally every 2 years, and are provided by a mixture of public and private organisations, which may or may not be publically financed. Therefore, the differences in the provision of screening services indicate that the psychological effects of this experience and the impact on returning for screening 
remains unclear in the particular health service and cultural context of the UK.

To address this knowledge gap we conducted a systematic review of studies in the UK population of the medium to long-term psychological consequences of experiencing a false-positive screening mammogram and whether these affect future attendance at mammography screening. In addition qualitative studies, an important underpinning to the understanding of psychological consequences, did not appear to have been searched for in previous reviews, so we particularly targeted these in our study.

The definition of a false-positive mammogram used in this study is that given by the WHO: 'an abnormal mammogram (one requiring further assessment) in a woman ultimately found to have no evidence of cancer ${ }^{16}$ and the American College of Radiology categories of mammographies considered as abnormal are detailed in http:// www.imaginis.com/mammography/mammograminterpretation-categories-and-the-acr-bi-rads.

\section{Methods}

This systematic review was carried out following the principles published by the NHS Centre for Reviews and Dissemination. ${ }^{17}$ The study protocol can be found in appendix 1.

\section{Inclusion criteria}

Studies were included if based in the UK, populated by women whose experience met the above definition of a false-positive screening mammogram, the comparator group were those with a normal screening mammogram, the outcomes were psychological, behavioural or those from qualitative studies and follow-up was at least 1 month from the 'all clear'. All controlled studies and qualitative designs were included. Case studies were excluded.

\section{Search strategy}

The search strategy consisted of searching of electronic bibliographic databases, internet searches, scrutiny of references of included studies and contacting experts in the field.

The following electronic databases were searched in December 2010: Medline, Medline in Process and other Non-Indexed Citations, EMBASE, HMIC, Cochrane Central, Cochrane CDSR, CRD Dare, CRD HTA, Cochrane Methodology, Web of Science, Psychinfo, Cinahl, Sociological Abstracts, the International Bibliography of the Social Sciences and Zetoc. Ongoing trials were searched for at: UKCRN, Controlled Trials.com, Clinical Trials.gov, ICTRP (WHO International Clinical Trials Registry Platform), UK Database of Uncertainties about the Effects of Treatments (DUETs), a filter was applied to capture qualitative research as well as quantitative designs. Further searches for more qualitative and grey literature were run in January 2011 on the following databases: Medline in Process and other Non-Indexed Citations, Embase Classic and Embase, British Nursing Index and Archive, Social Policy and Practice, Cinahl plus, Cochrane Library, HMIC, PsycINFO, Assia, Sociological Abstracts, Web of Science, CRD and IBSS. All searches were run from inception to the then present date. Bibliographies of included studies were searched for further relevant studies. An update search was carried out on 26 November 2011. The MEDLINE search strategy is available in appendix 2.

Papers were selected for review from the titles and abstracts generated by the search strategy. This was done independently by two reviewers (MB and TP); discrepancies were resolved by discussion. Retrieved papers were again reviewed and selected against the inclusion criteria by the same independent process. Data were extracted from included studies by one reviewer using standardised data extraction forms and checked by another reviewer. Attempts were made to contact authors to provide missing information. Data were gathered on the design, participants, methods, outcomes, baseline characteristics and results of the studies.

\section{Quality assessment}

Studies were assessed for internal validity according to criteria suggested by the updated NHS CRD Report No. 4, according to study type. ${ }^{17}{ }^{18}$ Randomised controlled trials (RCTs) were appraised with the CONSORT statement ${ }^{19}$ and observational studies with STROBE guidelines. ${ }^{20}$ External validity was assessed according to the applicability of findings to a relevant patient group and service setting.

\section{Analysis}

Analysis was carried out using StatSEv12 software. The principle summary measures were relative risks with 95\% CI. All study designs had a narrative synthesis. Observational studies were considered for possible meta-analysis. Overall, they had considerable amounts of missing information so that it was difficult to judge heterogeneity. Therefore, a meta-analysis was not carried out.

\section{Results}

\section{Search results}

Our searches retrieved 4423 titles and abstracts after deduplication. When screening was complete we found seven primary studies (nine papers) that met the inclusion criteria. Four of the studies were prospective cohorts $^{21-25}$ four were retrospective cohorts, ${ }^{26-28}$ and one was an RCT of an intervention to improve reattendance. $^{29}$

Studies covered two domains: (a) three studies looked at the psychological impact of false-positive mammograms in the normal risk population; ${ }^{21-25}$ and (b) six looked at the impact of this experience on returning for routine mammogram screening, ${ }^{21} 22^{26-29}$ (some studies looked at both domains). No studies were found that were either about or that had subgroups of women from different ethnic, socioeconomic or other groups within the general screening population. No published qualitative studies were found. A flow chart of the selection process is in appendix 3 .

\section{Quality and characteristics}

The quality of the research was variable; the RCT was poor quality with few methodological details given, 
although some of the observational studies, notably those from the Oxford Primary Care Education Research Group, were reasonably well reported. However, the majority had a number of weaknesses, including a failure to consider the possible effects of bias and confounding on the results and a failure to report participants' demographic and other characteristics. These quality indicators appear to have been overlooked as in most cases there was no consideration of the limitations of the methods or conduct of the study. There were insufficient studies in each domain to produce a meaningful assessment of publication bias with a funnel plot. Table 1 provides summary characteristics of the included studies by their outcome domain. Appendix 4 shows a summary assessment of quality indicators.

\section{Study results}

Psychological impact

The studies of the psychological impact of falsepositive mammograms gave conflicting results. When disease specific measures were used that is, the Psychological Consequences Questionnaire ${ }^{30}$ an enduring negative impact was found for those with false-positive results compared to those with normal mammograms that lasted until 35 months from the last assessment. The degree of distress found was related to the level of invasiveness of the method of assessment used; so that at 35 months, women who had a biopsy were more distressed (relative risk (RR) 95\% CI 2.07 (1.22 to 3.52)) than women who had fine needle aspiration (RR 95\% CI 1.80 (1.17 to 2.77)), and non significantly; further mammography (RR 95\% CI 1.28 (0.82 to 2.00)). Additionally women placed on early recall were also at a greater relative risk of distress (RR 95\% CI 1.82 (1.22 to 2.72)). The greatest relative risk of distress was felt at 5 months after assessment and was significant for all assessment procedures (figure 1).

Conversely, when generic measures of general anxiety and depression were used, the Hospital Anxiety and Depression Scale ${ }^{31}$ (http://www.surreyhealth.nhs.uk/ dcp/Documents/D1.3d2.pdf) and the General Health Questionnaire-28 ${ }^{32}$ no significant differences were found between the two groups at 6 weeks after assessment and 3 months after screening. ${ }^{25} 24$ (figure 2).

\section{Reattendance}

The evidence for the impact of having a false-positive mammogram on returning for the next screening round is again conflicting. The forest plot below (figure 3) compares the relative risks of the reattendance studies. The evidence comes from four retrospective observational studies that collected data from registries and other NHS databases. The weight of evidence, in terms of the numbers of participants, is that women with false-positive mammograms are less likely to return for their next round of screening than women with normal mammograms, although the effect is small. The largest study with this finding $(\mathrm{N}=140387)$ had a relative risk of returning of 0.97 (95\% CI 0.96 to 0.98). ${ }^{26}$ Brett and Austoker ${ }^{22}$ came to the same conclusion, 0.92 (95\% CI 0.86 to 0.98). Two studies with a combined population of $\mathrm{N}=7231$ found that there was no such association but had wide 95\% CIs consistent with both increased and decreased likelihood of return. ${ }^{27} 28$

Evidence from a poor-quality RCT by Meldrum et $a l^{29} \quad(\mathrm{~N}=3083)$ suggests that this finding can be reversed if women are given screening invitation letters that are tailored to the outcome of their last screening (RR of returning (95\% CI) 1.10 (1.00 to 1.21)).

\section{Discussion}

The benefits and harms accruing from breast cancer screening are a matter of current UK concern.

Included studies, comparing psychological impact of false-positive mammograms to normal ones, gave conflicting results. When disease specific measures were used an enduring negative impact was found that lasted until 35 months with the degree of distress related to the invasiveness of the assessment. Conversely, when measures of general anxiety and depression were used no significant differences were found between the two groups. However, this could be explicable if we speculate that false-positive mammograms may lead to breast cancer-specific psychological distress, enduring for up to 3 years, but that it is unlikely that general anxiety or depression will occur.

Concerning reattendance, the weight of evidence is that women with false-positive mammograms are less likely to return for subsequent rounds of screening than women with normal mammograms.

No systematic reviews were found that are directly comparable to ours as they all include non-UK studies, may have populations younger than ours, measure outcomes at less than 1 month and have screening programmes based on opt-in or insurance payments. ${ }^{7} 10 \quad 11$ 13-15 Nevertheless, our results agree with theirs that there can be negative psychological consequences from having a false-positive mammogram and that reattendance can fall. Greater clarity has emerged by removing the effect of variation in the specific nature of different national programmes.

\section{Limitations}

The robustness of the findings of this systematic review are limited by the reliability of the poorly reported observational studies. The degree of heterogeneity between these studies is subsequently unknown. This meant that we were unable to pool the data (without potentially reporting spurious relationships) and thus provide an overall estimate of distress and reattendance. Additionally, the evidence in this systematic review is at least 10 years old and may also have been influenced by publication bias.

Our decision to restrict included studies to those in the UK may also be seen as a limitation. However we felt that this was a reasonable approach given the variability in results worldwide, the most obvious explanation for which was likely to be variation in programme. Detailed investigation of qualitative research was also felt to be more appropriately conducted at national level. Also despite the UK-specific nature of this review we believe that generalisable messages remain, as indicated below. 
Table 1 Summary characteristics of included studies by outcome domain

\begin{tabular}{|c|c|c|c|c|c|c|c|c|c|}
\hline $\begin{array}{l}\text { Study/author } \\
\text { year (funding) }\end{array}$ & Design & $\mathrm{N}$ & Participants & $\begin{array}{l}\text { Intervention } \\
\text { group }\end{array}$ & Control group & Outcomes & $\begin{array}{l}\text { Length of } \\
\text { follow-up }\end{array}$ & Exclusion criteria & Notes \\
\hline \multicolumn{10}{|c|}{ Psychological impact } \\
\hline $\begin{array}{l}\quad \text { Brett and } \\
\text { Austoker, } 2001 \\
\text { (Cancer } \\
\text { Research } \\
\text { Campaign) }\end{array}$ & $\begin{array}{l}\text { Prospective } \\
\text { cohort } \\
\text { multicentre } \\
\text { Psychological } \\
\text { impact }\end{array}$ & 505 & $\begin{array}{l}\text { Women invited for } \\
\text { routine screening by } \\
\text { mammogram, already } \\
\text { participating in the } \\
\text { study at } 5 \text { months }\end{array}$ & $\begin{array}{l}\text { Routine screening } \\
\text { by mammogram } \\
\text { with a } \\
\text { false-positive } \\
\text { result } N=375\end{array}$ & $\begin{array}{l}\text { Routine screening by } \\
\text { mammogram with a normal } \\
\text { result } N=130\end{array}$ & $\begin{array}{l}\text { PCQ intention to } \\
\text { reattend and actual } \\
\text { reattendance } \\
\text { satisfaction with } \\
\text { service ad hoc } \\
\text { questionnaire }\end{array}$ & $\begin{array}{l}3 \text { years } \\
\text { (35 months) } \\
\text { after } \\
\text { assessment }\end{array}$ & $\begin{array}{l}\text { Over } 65 \text { years, } \\
\text { symptomatic } \\
\text { referral, in } \\
\text { another study, } \\
\text { developed cancer }\end{array}$ & \\
\hline $\begin{array}{l}\text { Brett et al, } \\
1998 \text { (Cancer } \\
\text { Research } \\
\text { Campaign) }\end{array}$ & $\begin{array}{l}\text { Prospective } \\
\text { cohort } \\
\text { multicentre } \\
\text { Psychological } \\
\text { impact }\end{array}$ & 284 & $\begin{array}{l}\text { Women invited for } \\
\text { routine screening by } \\
\text { mammogram, already } \\
\text { participating in the } \\
\text { study at } 1 \text { month }\end{array}$ & $\begin{array}{l}\text { Routine screening } \\
\text { by mammogram } \\
\text { with a } \\
\text { false-positive } \\
\text { result } N=163\end{array}$ & $\begin{array}{l}\text { Routine screening by } \\
\text { mammogram with a normal } \\
\text { result } N=52\end{array}$ & $\begin{array}{l}\mathrm{PCQ} \text {, intention to } \\
\text { reattend, ad hoc } \\
\text { questionnaire }\end{array}$ & $\begin{array}{l}5 \text { months } \\
\text { after } \\
\text { assessment }\end{array}$ & As above & $\begin{array}{l}69(24 \%) \text { women } \\
\text { chose not to return } \\
\text { the questionnaire }\end{array}$ \\
\hline $\begin{array}{l}\text { Ong et al, } \\
\text { 1997a (Cancer } \\
\text { Research } \\
\text { Campaign, } \\
\text { NHSBSP) }\end{array}$ & $\begin{array}{l}\text { Prospective } \\
\text { cohort } \\
\text { multicentre } \\
\text { Psychological } \\
\text { impact }\end{array}$ & 877 & $\begin{array}{l}\text { Women invited for } \\
\text { routine screening by } \\
\text { mammogram recalled } \\
\text { for assessment }\end{array}$ & $\begin{array}{l}\text { Women placed on } \\
\text { early recall } \\
\text { ( } 3 \text { years) } \mathrm{N}=182\end{array}$ & $\begin{array}{l}\text { Women placed on routine } \\
\text { recall after mammography } \\
(\mathrm{N}=173) \text {, further } \\
\text { mammography assessment } \\
(\mathrm{N}=166), \mathrm{FNA}(\mathrm{N}=109) \text { or } \\
\text { biopsy }(\mathrm{N}=31)\end{array}$ & PCQ & $\begin{array}{l}1 \text { month after } \\
\text { assessment }\end{array}$ & Not reported & $\begin{array}{l}\text { This study was } \\
\text { primarily about the } \\
\text { effects of early recall } \\
\text { on women who had } \\
\text { been recalled after } \\
\text { their mammogram }\end{array}$ \\
\hline $\begin{array}{l}\quad \text { Bull and } \\
\text { Campbell, } 1991 \\
\text { (Yorkshire } \\
\text { Regional Health } \\
\text { Authority) }\end{array}$ & $\begin{array}{l}\text { Prospective } \\
\text { cohort } \\
\text { Psychological } \\
\text { impact }\end{array}$ & 750 & $\begin{array}{l}\text { Women invited for } \\
\text { routine screening by } \\
\text { mammogram recalled } \\
\text { for assessment }\end{array}$ & $\begin{array}{l}\text { Routine screening } \\
\text { by mammogram } \\
\text { with a } \\
\text { false-positive } \\
\text { result } N=308\end{array}$ & $\begin{array}{l}\text { Routine screening by } \\
\text { mammogram with a normal } \\
\text { result } N=420\end{array}$ & $\begin{array}{l}\text { Ad hoc questionnaire } \\
\text { including frequency of } \\
\text { breast } \\
\text { self-examination HADS }\end{array}$ & $\begin{array}{l}6 \text { weeks after } \\
\text { the 'all clear' }\end{array}$ & Not reported & $\begin{array}{l}\text { It is not known if the } \\
\text { women had } \\
\text { previously had } \\
\text { cancer or were in a } \\
\text { high risk group }\end{array}$ \\
\hline $\begin{array}{l}\quad \text { Ellman et al, } \\
1989 \text { (DHSS } \\
\text { Research } \\
\text { Management } \\
\text { Division) }\end{array}$ & $\begin{array}{l}\text { Prospective } \\
\text { cohort } \\
\text { Psychological } \\
\text { impact }\end{array}$ & 752 & $\begin{array}{l}\text { Women invited for } \\
\text { routine mammogram } \\
\text { screening and those } \\
\text { recalled for further } \\
\text { assessment and those } \\
\text { with symptoms being } \\
\text { further investigated }\end{array}$ & $\begin{array}{l}\text { Routine screening } \\
\text { by mammogram } \\
\text { with a } \\
\text { false-positive } \\
\text { result } N=271\end{array}$ & $\begin{array}{l}\text { Routine screening by } \\
\text { mammogram with a normal } \\
\text { result } N=295 \text {, symptomatic } \\
\text { women who did not have } \\
\text { cancer } N=134 \text {, } \\
\text { symptomatic or recalled } \\
\text { screened women who did } \\
\text { have cancer } N=38 \text {, history } \\
\text { of breast cancer with or } \\
\text { without symptoms } N=14\end{array}$ & $\begin{array}{l}\text { GHQ-28, ad hoc } \\
\text { questionnaire }\end{array}$ & $\begin{array}{l}3 \text { months } \\
\text { after clinic } \\
\text { attendance }\end{array}$ & Not reported & $\begin{array}{l}\text { Participants also } \\
\text { received clinical } \\
\text { examination. Only } \\
\text { those groups } \\
\text { meeting the } \\
\text { inclusion criteria will } \\
\text { be considered in this } \\
\text { systematic review }\end{array}$ \\
\hline \multicolumn{10}{|c|}{ Impact on reattendance } \\
\hline $\begin{array}{l}\quad \text { McCann et al, } \\
2002 \text { (NHS } \\
\text { Executive } \\
\text { Eastern Region) }\end{array}$ & $\begin{array}{l}\text { Retrospective } \\
\text { cohort } \\
\text { Reattendance } \\
\text { and interval } \\
\text { cancer }\end{array}$ & 140387 & $\begin{array}{l}\text { Women } 49-63 \text { years } \\
\text { invited for routine } \\
\text { breast screening by } \\
\text { mammography }\end{array}$ & $\begin{array}{l}\text { Routine screening } \\
\text { by mammogram } \\
\text { with a } \\
\text { false-positive } \\
\text { result } N=4792\end{array}$ & $\begin{array}{l}\text { Routine screening by } \\
\text { mammogram with a normal } \\
\text { result } N=108617\end{array}$ & $\begin{array}{l}\text { Subsequent } \\
\text { attendance at routine } \\
\text { screening after a } \\
\text { false-positive result } \\
\text { and rate of interval } \\
\text { cancer-from records }\end{array}$ & 3 years & $\begin{array}{l}\text { Women who were } \\
\text { older than } \\
63 \text { years at } \\
\text { follow-up }\end{array}$ & \\
\hline
\end{tabular}


Table 1 Continued

\begin{tabular}{|c|c|c|c|c|c|c|c|c|c|}
\hline $\begin{array}{l}\text { Study/author } \\
\text { year (funding) }\end{array}$ & Design & $\mathrm{N}$ & Participants & $\begin{array}{l}\text { Intervention } \\
\text { group }\end{array}$ & Control group & Outcomes & $\begin{array}{l}\text { Length of } \\
\text { follow-up }\end{array}$ & Exclusion criteria & Notes \\
\hline $\begin{array}{l}\text { O'Sullivan } \\
\text { et al, } 2001 \\
\text { (Cancer } \\
\text { Research } \\
\text { Campaign) }\end{array}$ & $\begin{array}{l}\text { Retrospective } \\
\text { cohort } \\
\text { Reattendance }\end{array}$ & 5649 & $\begin{array}{l}\text { Women invited for } \\
\text { mammography } \\
\text { screening for the } \\
\text { second or more time }\end{array}$ & $\begin{array}{l}\text { Routine screening } \\
\text { by mammogram } \\
\text { with a } \\
\text { false-positive } \\
\text { result } N=248\end{array}$ & $\begin{array}{l}\text { Routine screening by } \\
\text { mammogram with a normal } \\
\text { result } N=5401\end{array}$ & $\begin{array}{l}\text { Subsequent } \\
\text { attendance at routine } \\
\text { screening after a } \\
\text { false-positive result- } \\
\text { from records }\end{array}$ & $\begin{array}{l}\text { Unclear, } \\
\text { probably from } \\
1989 \text { to } 1997\end{array}$ & $\begin{array}{l}\text { Women invited for } \\
\text { the first time and } \\
\text { women who had } \\
\text { been previously } \\
\text { invited but had } \\
\text { never attended }\end{array}$ & $\begin{array}{l}\text { Effects of a } \\
\text { false-positive result } \\
\text { on reattendance for } \\
\text { those on early recall } \\
\text { and routine recall }\end{array}$ \\
\hline $\begin{array}{l}\quad \text { Brett and } \\
\text { Austoker, } 2001 \\
\text { (Cancer } \\
\text { Research } \\
\text { Campaign) }\end{array}$ & $\begin{array}{l}\text { As above in } \\
\text { psychological } \\
\text { impact }\end{array}$ & & & & & & & & \\
\hline $\begin{array}{l}\text { Brett et al, } \\
1998 \text { (Cancer } \\
\text { Research } \\
\text { Campaign) }\end{array}$ & $\begin{array}{l}\text { As above in } \\
\text { psychological } \\
\text { impact }\end{array}$ & & & & & & & & \\
\hline $\begin{array}{l}\text { Meldrum, } \\
1994 \text { (Scottish } \\
\text { Office Home and } \\
\text { Health } \\
\text { Department) }\end{array}$ & $\begin{array}{l}\text { RCT-nested } \\
\text { telephone } \\
\text { interview study }\end{array}$ & 3083 & $\begin{array}{l}\text { All women invited for } \\
\text { second round routine } \\
\text { mammography } \\
\text { screening } \\
\text { ( } 50-65 \text { years) }\end{array}$ & $\begin{array}{l}\text { Tailored invitation } \\
\text { with a } \\
\text { false-positive } \\
\text { result } N=115 \text { and } \\
\text { with normal } \\
\text { result } N=800\end{array}$ & $\begin{array}{l}\text { Standard invitation with a } \\
\text { false-positive result } \mathrm{N}=112 \\
\text { and with a normal result } \\
\mathrm{N}=791\end{array}$ & $\begin{array}{l}\text { Subsequent } \\
\text { attendance at routine } \\
\text { screening and effect } \\
\text { of a tailored invitation } \\
\text { on subgroups }\end{array}$ & Not reported & $\begin{array}{l}\text { Women with } \\
\text { breast cancer and } \\
\text { those whose } \\
\text { screening history } \\
\text { was not available }\end{array}$ & $\begin{array}{l}\text { Trial comparing the } \\
\text { effect of a tailored } \\
\text { invitation on second } \\
\text { round screening } \\
\text { attendance with a } \\
\text { standard invitation }\end{array}$ \\
\hline $\begin{array}{l}\text { Orton, } 1991 \\
\text { (funding not } \\
\text { reported) }\end{array}$ & $\begin{array}{l}\text { Retrospective } \\
\text { cohort } \\
\text { Reattendance }\end{array}$ & 1582 & $\begin{array}{l}\text { Women, aged } 45-64 \text {, } \\
\text { invited to attend for } \\
\text { second round } \\
\text { screening by } \\
\text { mammography }\end{array}$ & $\begin{array}{l}\text { Routine screening } \\
\text { by mammogram } \\
\text { with a } \\
\text { false-positive } \\
\text { result } N=50\end{array}$ & $\begin{array}{l}\text { Routine screening by } \\
\text { mammogram with a normal } \\
\text { result } N=1532\end{array}$ & $\begin{array}{l}\text { Reattendance } \\
\text { acceptability of } \\
\text { screening }\end{array}$ & NA & Not reported & $\begin{array}{l}\text { Data are not } \\
\text { available for the } \\
\text { acceptability of } \\
\text { screening for } \\
\text { false-positive } \\
\text { participants }\end{array}$ \\
\hline
\end{tabular}

FNA, fine needle aspiration; HADS, Hospital Anxiety and Depression Scale; NA, not applicable; PCQ, Psychological Consequences Questionnaire; RCT, randomized controlled trial. 


\section{Study}

ID

$\operatorname{RR}(95 \% \mathrm{Cl})$

Further_mammography

Ong et al. T1

Brett et al. T1

Brett et al. T2

Brett \& Austoker T1

Brett \& Austoker T3

FNA

Ong et al. T1

Brett et al. T1

Brett et al. T2

Brett \& Austoker T1

Brett \& Austoker T3

Biopsy

Ong et al. T1

Brett et al. T1

Brett et al. T2

Brett \& Austoker T1

Brett \& Austoker T3

Early_recall

Ong et al. T1

Brett et al. T1

Brett et al. T2

Brett \& Austoker T1

Brett \& Austoker T3

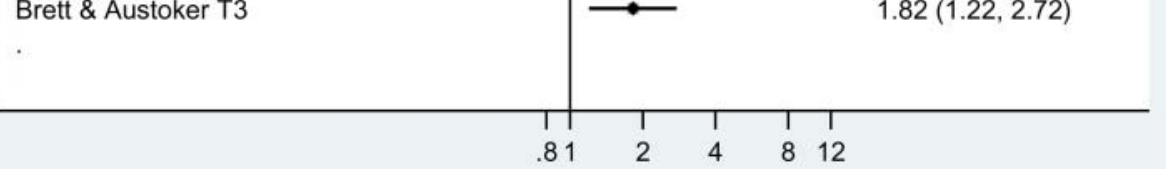

Figure 1 Forest plot of the relative risks of negative psychological consequences from having a false-positive mammogram compared to a normal one by type of false-positive assessment, at T1 (1 month after assessment), T2 (5 months after assessment) and T3 (35 months after assessment), measured with the PCQ.

\section{Implications for policy and future research}

Policy makers, particularly in the UK should consider the impact of false-positive mammograms when planning breast screening services. Measures need to be taken to reduce the distress caused; however, the evidence base for such measures is lacking. Internationally the need to take account of the context of the evaluations is illustrated and absence of supporting qualitative research to understand the underlying nature of psychological consequences in the UK is likely to have parallels in other countries.

Therefore, further research is needed to increase and update our understanding of the harms of breast cancer screening. In particular a qualitative interview study would further our appreciation of what this experience means to women, and principally shed light on how the subtleties of difference in response to assessment procedures relate to anxiety and probability of reattendance. Consequently, the authors are currently conducting such an interview study. Well-designed observational studies are also needed, that use disease specific and generic outcome measures in order to determine the degree and kind of negative psychological outcomes. Studies should include women from different ethnic and socioeconomic groups and routinely collect demographic information so that future systematic reviews may be able to judge whether the pooling of data is legitimate.

\section{Conclusions}

We conclude that the experience of having a falsepositive screening mammogram can cause breast cancer-specific psychological distress that may endure for 3 years. However, it is less likely that there will be pathological general anxiety and depression. The distress caused by a false-positive mammogram may be 


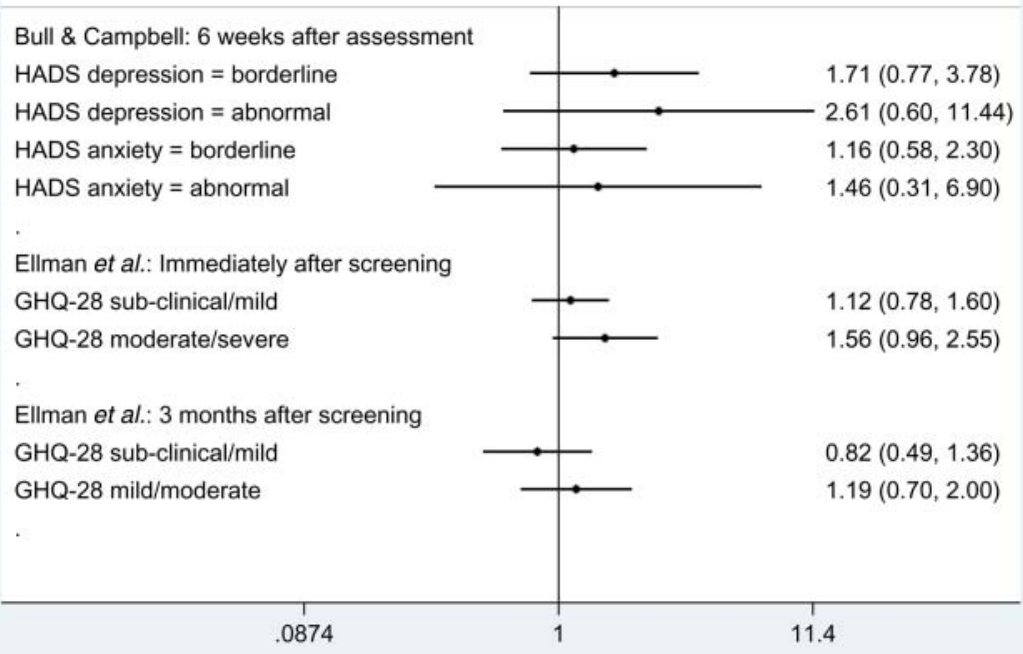

Figure 2 Relative risk of suffering clinically measurable levels of general anxiety and depression following a false-positive mammogram compared to a normal mammogram, measured by Bull and Campbell (HADS) and Ellman et al (GHQ-28).

sufficient to deter some women from attending their next breast cancer screening appointment.

- Additional data is published online only. To view this file please visit the journal online (http://ebm.bmj.com).

Funding This project was funded by the NIHR Health Technology Assessment programme (project number 09/145/01) and will be published in full in the Health Technology Assessment journal, Vol. [x], No. [x]. See the
HTA programme website for further project information. SD was funded by the NIHR through the Peninsula Collaboration for Leadership in Applied Health Research and Care.

Disclaimer The views and opinions expressed therein are those of the authors and do not necessarily reflect those of the Department of Health.

Study

ID

$\mathrm{RR}(95 \% \mathrm{Cl})$

McCann et al.

O'Sullivan et al.

Brett \& Austoker

Orton et al.

Meldrum et al.

$0.97(0.96,0.98)$

$0.99(0.91,1.08)$

$0.92(0.86,0.98)$

$1.03(0.95,1.13)$

$1.10(1.00,1.21)$

$\begin{array}{llll}.86 & .92 & 1 & 1.081 .13\end{array}$

Figure 3 Forest plot of the likelihood of failing to reattend the next round of mammography screening following a false-positive mammogram compared to having a normal one. 


\section{Competing interests None.}

Correction notice This article has been corrected since it was published Online First. Reference 33 was a repeat of reference 27 and so has been deleted from the article.

\section{References}

1. Godlee F. Mammography wars. BMJ 2011;343:d7623.

2. Thornton H, Pryke M, Mackie A. Mammography wars: rapid responses. BMJ 2011;343:d7623. http://www.bmj.com/content/ 343/bmj.d7623?tab=responses

3. Kopans DB, Smith RA, Duffy SW. Mammographic screening and overdiagnosis. Radiology 2011;260:616-20.

4. Gotzsche PC, Nielsen M. Screening for breast cancer with mammography. Cochrane Rev 2011;(7):CD001877.

5. Jorgensen KJ, Gotzsche PC. Overdiagnosis in publicly organised mammography screening programmes: systematic review of incidence trends. BMJ 2009;339:b2587.

6. Seigneurin A, Francois O, Labarere J, et al. Overdiagnosis from non-progressive cancer detected by screening mammography: stochastic simulation study with calibration to population based registry data. BMJ 2011;343:d7071.

7. Brewer NT, Salz T, Lillie SE. Systematic review: the long-term effects of false-positive mammograms. Ann Intern Med 2007;146:502-10.

8. Marteau TM, Cook R, Kidd J, et al. The psychological effects of false-positive results in prenatal screening for fetal abnormality: a prospective study. Prenat Diagn 1992;12:205-14.

9. French DP, Maissi E, Marteau TM. The psychological costs of inadequate cervical smear test results: three-month follow-up. Psychooncology 2006;15:498-508.

10. Salz T, Richman AR, Brewer NT. Meta-analyses of the effect of false-positive mammograms on generic and specific psychosocial outcomes. Psycho Oncol 2010;19:1026-34.

11. Hafslund B, Nortvedt MW. Mammography screening from the perspective of quality of life: a review of the literature. Scand $J$ Caring Sci 2009;23:539-48.

12. Armstrong K, Moye E, Williams S, et al. Screening mammography in women 40 to 49 years of age: a systematic review for the American College of Physicians. Ann Intern Med 2007;146:516-26.

13. Brett J, Bankhead C, Henderson B, et al. The psychological impact of mammographic screening. A systematic review. Psycho Oncol 2005;14:917-38.

14. Bankhead CR, Brett J, Bukach C, et al. The impact of screening on future health-promoting behaviours and health beliefs: a systematic review. Health Technol Assess 2003;7:1-92.

15. Armstrong K, Moye E, Williams S, et al. Clinical guidelines. Screening mammography in women 40 to 49 years of age: a systematic review for the American College of Physicians. Ann Intern Med 2007;146:516.

16. International Agency for Research on Cancer, W.H.O. (2002). Breast Cancer Screening (Rep. No. 7), Lyon, France: IARC Press.
17. NHS Centre for Reviews and Dissemination. Systematic reviews: CRD's guidance for undertaking reviews in health care. York: NHS Centre for Reviews and Dissemination, 2009.

18. Egger M, Smith GD, Altman DG. Systematic reviews in health care: meta-analysis in context. 2nd edn. London: BMJ, 2001.

19. Moher D, Schulz KF, Altman DG. The CONSORT statement: revised recommendations for improving the quality of reports of parallel-group randomised trials. Lancet 2001;357: 1191-4.

20. Elm Ev, Altman DG, Egger M, et al. Strengthening the reporting of observational studies in epidemiology (STROBE) statement: guidelines for reporting observational studies. $B M J$ 2007;335:806-8.

21. Brett J, Austoker J, Ong G. Do women who undergo further investigation for breast screening suffer adverse psychological consequences? A multi-centre follow-up study comparing different breast screening result groups five months after their last breast screening appointment. J Public Health 1998;20:396-403.

22. Brett J, Austoker J. Women who are recalled for further investigation for breast screening: psychological consequences 3 years after recall and factors affecting re-attendance. J Public Health 2001;23:292-300.

23. Ong G, Austoker J, Brett J. Breast screening: adverse psychological consequences one month after placing women on early recall because of a diagnostic uncertainty. A multicentre study. J Med Screen 1997;4:158-68.

24. Ellman R, Angeli N, Christians A, et al. Maguire P. Psychiatric morbidity associated with screening for breast cancer. $\mathrm{Br} \mathrm{J}$ Cancer 1989;60:781-4.

25. Bull AR, Campbell MJ. Assessment of the psychological impact of a breast screening programme. Br J Radiol 1991; 64:510-15.

26. McCann J, Stockton D, Godward S. Impact of false-positive mammography on subsequent screening attendance and risk of cancer. Breast Cancer Res 2002;4:R11.

27. O'Sullivan I, Sutton S, Dixon S, et al. False positive results do not have a negative effect on reattendance for subsequent breast screening. J Med Screen 2001;8:145-8.

28. Orton M. Factors affecting women's response to an invitation to attend for a second breast cancer screening examination. $\mathrm{Br} \mathrm{J}$ Gen Pract 1991;349:320-2.

29. Meldrum P, Turnbull D, Dobson HM, et al. Tailored written invitations for second round breast cancer screening: a randomised controlled trial. J Med Screen 1994;1:245-8.

30. Cockburn J, De Luise T, Hurley S, et al. Development and validation of the PCQ: a questionnaire to measure the psychological consequences of screening mammography. Soc Sci Med 1992;34:1129-34.

31. Zigmond AS, Snaith RP. The hospital anxiety and depression scale. Acta Psychiatr Scand 1983;67:361-70.

32. Goldberg DP. Manual of the general health questionnaire. Windsor, UK: NFER-Nelson Publishing, 1978. 